\title{
The Diacyclops languidoides - group (Copepoda : Cyclopoida) in Austria, with redescription of Diacyclops cohabitatus Monchenko 1980
}

\author{
F. Stoch 1 \\ P. Pospisil ${ }^{2}$
}

Keywords : copepods, cyclopoids, Diacyclops, groundwater, Austria.

Diacyclops cohabitatus Monchenko 1980 known only from the groundwater of the Carpathian mountains in Ukraine is redescribed from specimens collected in the Danube alluvial plain, the Lobau, at Vienna. In this area two stygobiont species belonging to the $D$. languidoides - group co-occur as well. D. cohabitatus can be differentiated from these latter Diacyclops species on the basis of several morphological traits of antennae, P4 and caudal rami. Its relationship with other members of the D. languidoides - group (e.g. D. languidoides goticus) is discussed.

Le groupe Diacyclops languidoides (Copepoda : Cyclopoida) en Autriche, avec la redescription de Diacyclops cohabitatus Monchenko 1980

Mots-clés : Copépodes, Cyclopoïdes, Diacyclops, eaux souterraines, Autriche.

Diacyclops cohabitatus Monchenko 1980 connue seulement des eaux souterraines des Carpathes en Ukraine est redécrit à pàrtir des exemplaires trouvés dans la plaine alluviale du Danube, le Lobau, à Vienne. D. cohabitatus coexiste dans le Lobau avec deux autres espèces stygobiontes du groupe $D$. languidoides. $D$. cohabitatus peut être différenciée de ces deux dernières espèces à partir de plusieurs traits morphologiques des antennes, des $\mathrm{P} 4$ et des branches furcales. Ses relations avec d'autres membres du groupe $D$ : languidoides (e.g. D. languidoides goticus) sont discutées.

\section{Introduction}

The earliest record assignable to the Diacyclops languidoides-group from Austria is probably that of Chappuis (1934), who reported Diacyclops languidoides f. gotica Kiefer 1931 from the cave named «Mausrodlhöhle» (Lower Austria). Thirty years later, Kiefer (1964) cited «Diacyclops cf. languidoides aut.» from the alluvial groundwater in Vienna. D. langui-

1. Museum of Natural History, Verona, Italy. Current address : Viale XXV Aprile 24, I-34015, Muggia (Trieste), Italy. E-mail: fabiocop@tin.it

2. Institute of Limnology, Austrian Academy of Sciences, A-5310 Mondsee, Austria. Current address : Reichmanngasse 3/6, A-1160 Vienna, Austria. E-mail: peter.pospisil@netway.at doides was subsequently cited from Austrian groundwaters by several other students (Priesel-Dichtl 1959, Löffler 1960a, b, Tilzer 1968, Vornatscher, 1972, Danielopol 1983, Pospisil 1994a, Gaviria 1998). Considering that the taxonomy of the $D$. languidoides-group involves several species which can be differentiated only using subtle morphological characters (Stoch, in press), it became vital to describe any species in detail. In recent publications (Pospisil 1994a, Pospisil \& Stoch 1999 , Stoch \& Pospisil in press) we revised the material collected by one of us (P. Pospisil) from the alluvial plain (Lobau-wetland) of the Danube in Vienna. Moreover, considering that the material examined by Chappuis (op. cit.) is no more available (O. Moldovan, pers. comm. F. S.), we collected Diacyclops material from the siphon pool of Mausrodlhöhle. Finally, we reexamined the Kiefer collection in the Staatliches $\mathrm{Mu}$ - 
seum für Naturkunde in Karlșruhe, including a specimen, mounted on slide, collected in a well near Vienna. The re-examination of this large amount of material from Austria revealed at least seven species of Diacyclops occurring in the Danube groundwaters near Vienna.

Besides the widespread, epigean species D. bicuspidatus (Claus 1857), six species exhibit the segmentation pattern of P1-P4 (exopods/endopods) 2/2, 3/2, 3/3, $3 / 3$. Following current taxonomic practice two of them, having 16-segmented antennules, were ascribed (Stoch \& Pospisil, in press) to the D. languidus-group: $D$. languidus (Sars 1863) and D. disjunctus (Thallwitz 1927). The remaining four species, having 11-segmented antennules, can be assigned to the Diacyclops languidoides-group: Diacylops danielopoli Pospisil \& Stoch 1999 and D. felix Pospisil \& Stoch 1999 were recently described as new species, while $D$. cohabitatus Monchenko 1980 and $D$. languidoides goticus Kiefer 1931 are reported herein for the first time.

\section{Material and methods}

The samples in the alluvial plain of the Danube near Vienna were collected from groundwater piezometers (diameter of $5 \mathrm{~cm}$ ) using a double-packer- sampler and then filtered through a $100 \mu \mathrm{m}$ sieve; those from the siphon pool of Mausrodlhöhle were collected using a $100 \mu \mathrm{m}$ plankton-net. The samples were stored in $4 \%$ formaldehyde.

Copepods were extracted under a stereomicroscope ; selected specimens were dissected in glycerine, and permanently mounted on slides in glycerine sealed with Caedax or epoxids. A Zeiss Axioskop microscope fitted with a drawing tube was used to study the details at 1000X using an oil immersion lens.

The terminology related to the external morphology follows Huys \& Boxshall (1991).

\section{Taxonomic account}

Family Cyclopidae Burmeister 1834

Subfamily Cyclopinae Dana 1853 emend. Kiefer 1927

\subsection{Diacyclops cohabitatus Monchenko 1980}

Synonymy : Diacyclops languidoides f. gotica : Chappuis 1934 : 211 ; Diacyclops languidoides «A» : Pospisil 1994a : 93.

Material examined : 51 males and 53 females, «Lobau»-wetland (Vienna) A81, A84, A87, and A89, (leg. P. Pospisil, 1991-1993; map of locations in Pospisil 1994a, 1994b). 1 male and 2 females, siphon pool of «Mausrodlhöhle» (number 1824/9 of the Austrian cave cadastre), Lunz am See, Niederösterreich (leg. F. Stoch \& P. Pospisil, 23/08/1996).

\section{Female}

Length, excluding caudal setae, 527-850 $\mu \mathrm{m}$ (average length $639 \mu \mathrm{m}, \mathrm{n}=53$ specimens). Hyaline fringes of posterior margins of urosomites not crenulate ; urosomites with dorsal and ventral sides smooth. Genital double somite broadest in anterior half, tapering posteriorly, longer than wide (Fig. 1a). Seminal receptacle with broader anterior part, posterior expansion little produced. Anal somite with lateral rows of spinules on distal margin, bearing 2 sensilla on dorsal surface ; anal operculum broad, slightly convex and weakly sclerotized.

Caudal ramus about 3.3 times longer than wide, average length $58 \mu \mathrm{m}(51-69 \mu \mathrm{m})$, without ornamentation (Fig. 1a). Anterolateral caudal seta longer than width of caudal ramus (average length $25 \mu \mathrm{m}$ ) ; terminal accessory seta shorter than caudal ramus and about 1.6 times longer than posterolateral seta, their average lengths respectively 60 and $38 \mu \mathrm{m}$; average values of outer and inner terminal setae length 159 and $327 \mu \mathrm{m}$; dorsal seta slightly longer (112\%) than caudal ramus (average length $65 \mu \mathrm{m}$ ).

Antennule 11-segmented (Fig. 1 ) ; segment 1 with a short comb of spinules, surfaces of the other segments smooth ; segment 8 with 1 aesthetasc. Segments (with number of setae and aesthetascs in brackets) : 1 [8], 2 [4], 3 [8], 4 [4], 5 [2], 6 [2], 7 [3], 8 [1+1aesthetasc], 9 [2], 10 [3], 11 [8].

Antenna (Fig. 1c,d,e) : coxa unarmed; basis with spinulation pattern as in Fig. 1d,e ; exopodal seta present. Endopod segment 1 with 1 seta, segment 2 with 9 setae, segment 3 with 7 distal setae.

Labrum typical of the genus. Mandible (Fig. 2a) : coxa without spinules, gnathobase with 5 stout teeth, sometimes multiple, a comb of spinules and 1 spinulose seta ; mandibular palp represented by 1 short and 2 long plumose setae. Maxillule (Fig. 2b) comprising praecoxa and maxillulary palp ; praecoxal endite typical of the genus Diacyclops ; surface of palp segment 1 (derived from coxa and basis) smooth ; palp segment 2 (endopod) bearing 3 setae ; exopodal seta present. Maxillary syncoxa (Fig. 2c) typical of subfamily, bearing 3 endites; basis with 1 claw and 2 setae ; endopod segment 1 bearing 2 setae, segment 2 with 3 setae. Maxilliped (Fig. 2d) 4-segmented ; second endopodal segment with 1 spinulose seta and 2 short naked setae. 


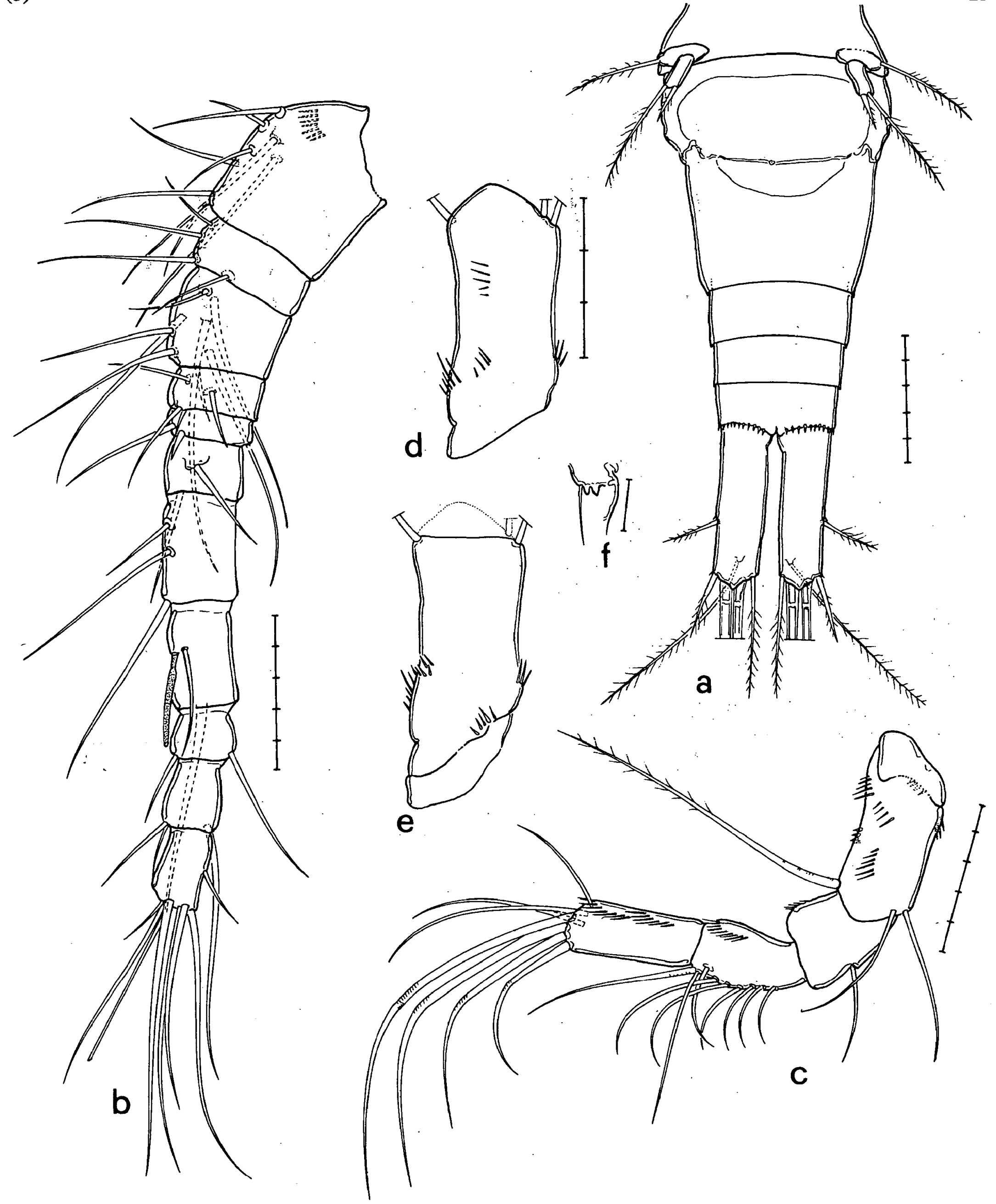

Fig. 1. Diacyclops cohabitatus female : a) abdomen and caudal rami, ventral view ; b) antennule ; c) antenna ; d) antennary basis with spinule pattern, caudal side ; e) ibidem, frontal side ; f) P6. Scale bars : $50 \mu \mathrm{m}$ (a,b,c), $30 \mu \mathrm{m}$ (d,e), $10 \mu \mathrm{m}$ (f).

Fig. 1. Diacyclops cohabitatus femelle : a) abdomen et branches furcales, vue ventrale ; b) antennule ; c) antenne ; d) basis de l'antenne, avec la disposition des épines de la face caudale ; e) de même, face frontale ; f) P6. Echelles : $50 \mu \mathrm{m}(\mathrm{a}, \mathrm{b}, \mathrm{c}), 30 \mu \mathrm{m}(\mathrm{d}, \mathrm{e}), 10$ $\mu \mathrm{m}(\mathrm{f})$. 


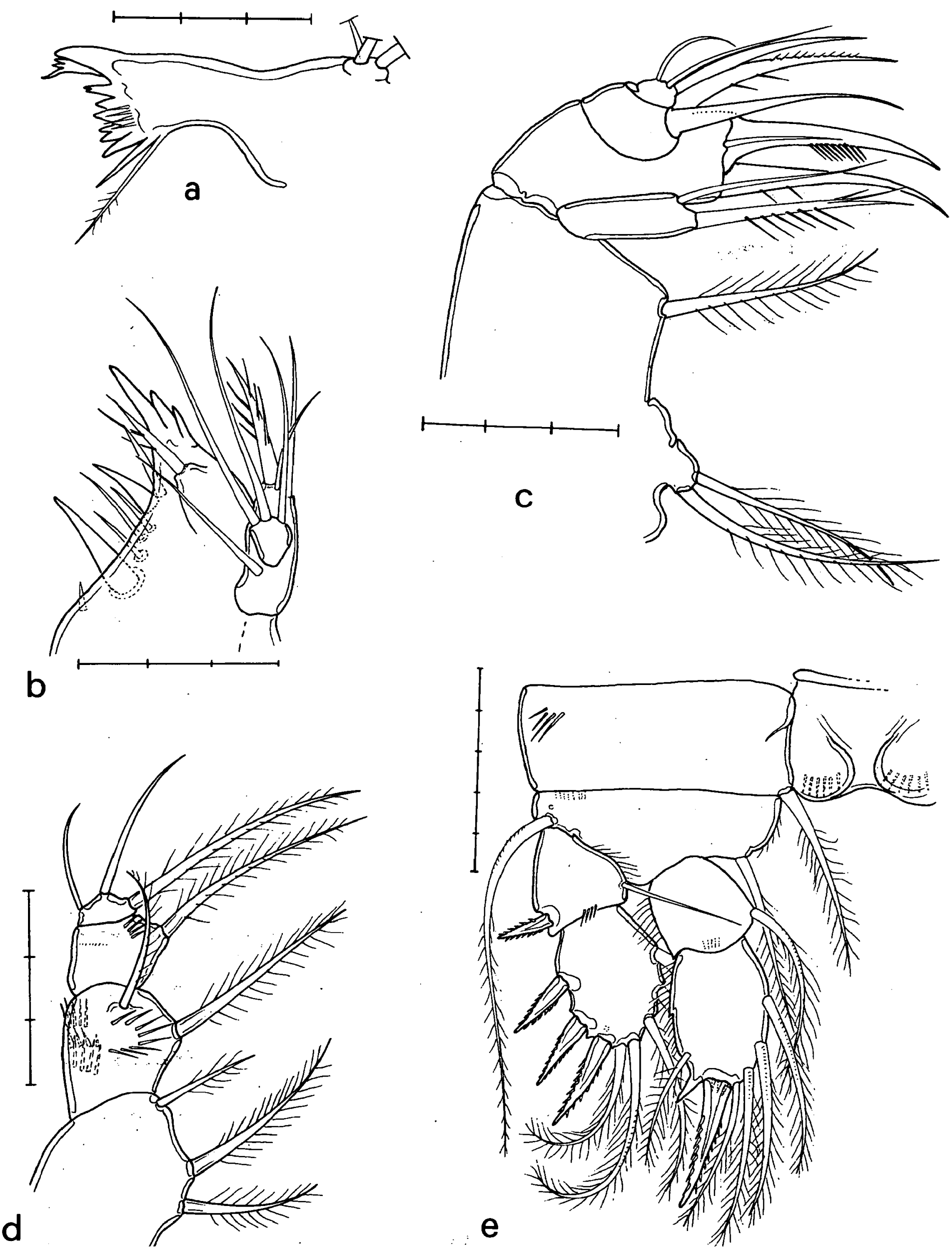

Fig. 2. Diacyclops cohabitatus female : a) mandible ; b) maxillule ; c) maxilla ; d) maxilliped ; e) P1. Scale bars : $50 \mu \mathrm{m}$ (e), $30 \mu \mathrm{m}$ (a,b,c,d).

Fig. 2. Diacyclops cohabitatus femelle : a) mandibule ; b) maxillule ; c) maxille ; d) maxillipède ; e) P1. Echelles : $50 \mu \mathrm{m}(\mathrm{a}, \mathrm{e}, \mathrm{f}), 30$ $\mu \mathrm{m}(\mathrm{b}, \mathrm{c}), 10 \mu \mathrm{m}(\mathrm{d})$. 

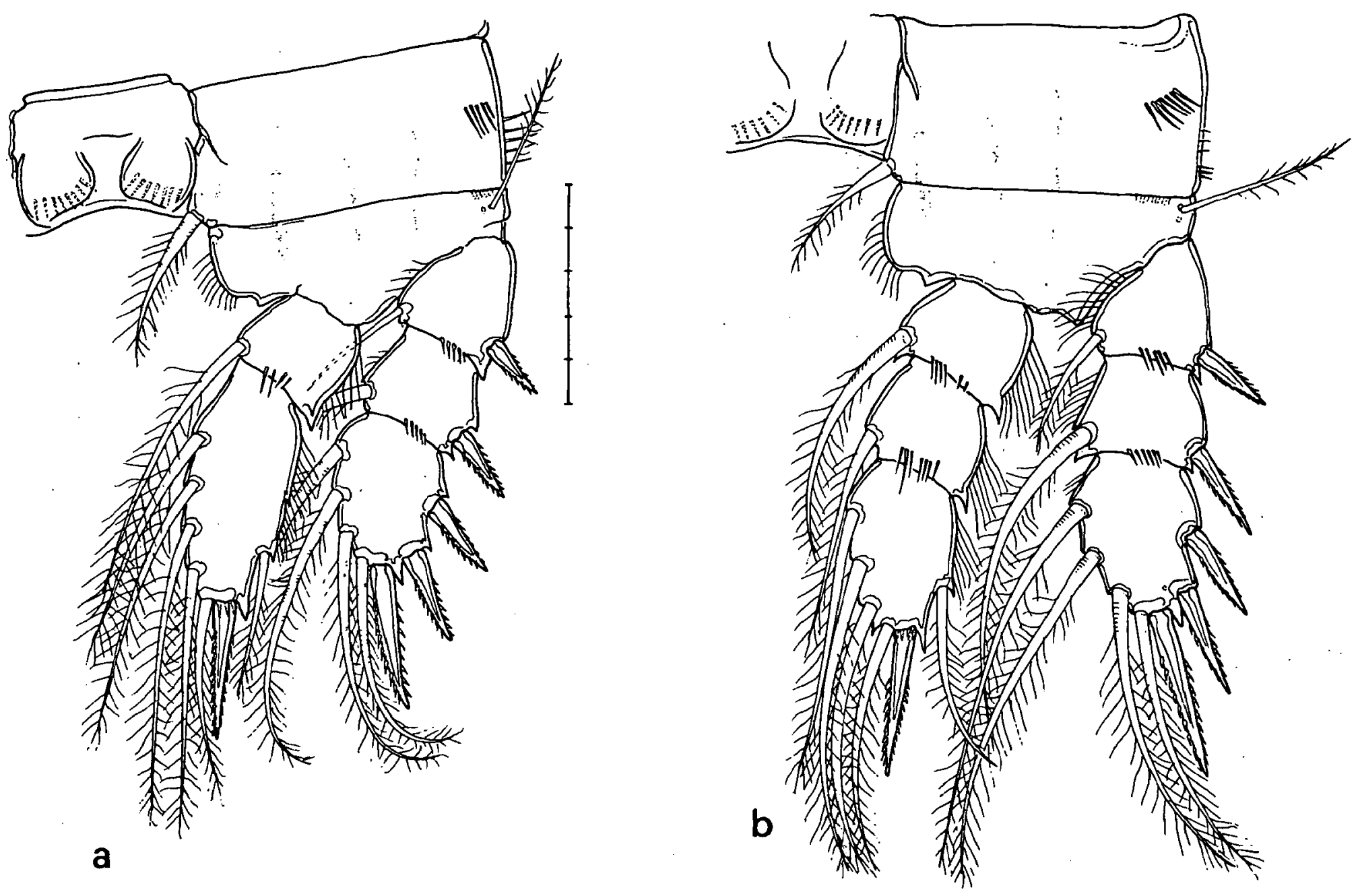

Fig. 3. Diacyclops cohabitatus female: a) P2 ; b) P3. Scale bars : $50 \mu \mathrm{m}$.

Fig. 3. Diacyclops cohabitatus femelle : a) P2 ; b) P3. Echelle : $50 \mu \mathrm{m}$.

Swimming legs : segmentation pattern of P1-P4 : $2 / 2,3 / 2,3 / 3,3 / 3$ (Figs. $2 e, 3 a, 3 b, 4 b$ ) ; pores as in the above mentioned figures. Distal segments of exopods $1-4$ with $3,3,3,3$ spines and $5,4,4,4$ setae, respectively. Intercoxal sclerites ornamented with spinules and setules. P4 (Fig. 4b) : coxa with spinulation pattern as in figure ; basis inner margin with a distinct notch and a sclerified tooth ; third endopodal segment 1.46-2.18 times longer than wide (average value 1.76 ) ; inner terminal spine 0.84-1.10 times longer than segment (average value 0.97 ), longer than outer terminal spine. P5 (Fig. 1a) : protopodal segment with 1 outer plumose seta and 1 pore ; exopodal segment twice as long as wide, armed with 1 seta and 1 inner spine shorter than segment. P6 bearing 2 short spinous processes and 1 seta (Fig. 1f).

\section{Male}

Length, excluding caudal setae, 458-593 $\mu \mathrm{m}$ (average length $522 \mu \mathrm{m}, \mathrm{n}=51$ specimens). Hyaline fringes of posterior margins of urosomites smooth. Caudal ramus about 3 times longer than wide, average length
$47.4 \mu \mathrm{m}(40-55 \mu \mathrm{m})$ (Fig. 4a). Proportion of lengths of setae much as in female.

Antennule digeniculate, 17-segmented ; neocopepodan distal geniculation between segments 14 and 15 (Fig. 4c). Segments 1, 4, 9 and 13 bearing aesthetascs, typical of subfamily and of the genus (Pospisil \& Stoch 1997, 1999, Stoch \& Pospisil, in press). Segments (with number of setae and aesthetascs in brackets): 1 [ $8+3$ aesthetascs], 2 [3], 3 [2], 4 [2+1 aesthetasc], 5 [1], 6 [2], 7 [1], 8 [1], 9 [2 +1 aesthetasc], 10 [1], 11 [2], 12 [2], 13 [1 + 1 aesthetasc], 14 [1], 15 [1], 16 [5], 17 [7].

Antenna and other appendages as in female. P6 forming opercular plate and bearing 3 slender setae (Fig. 4a).

Remarks - The material from the Lobau-area matches well with the description given by Monchenko (1980) except some minor details regarding the elongation of caudal rami and antennulary segments, more slender in the specimens from Ukraine. 


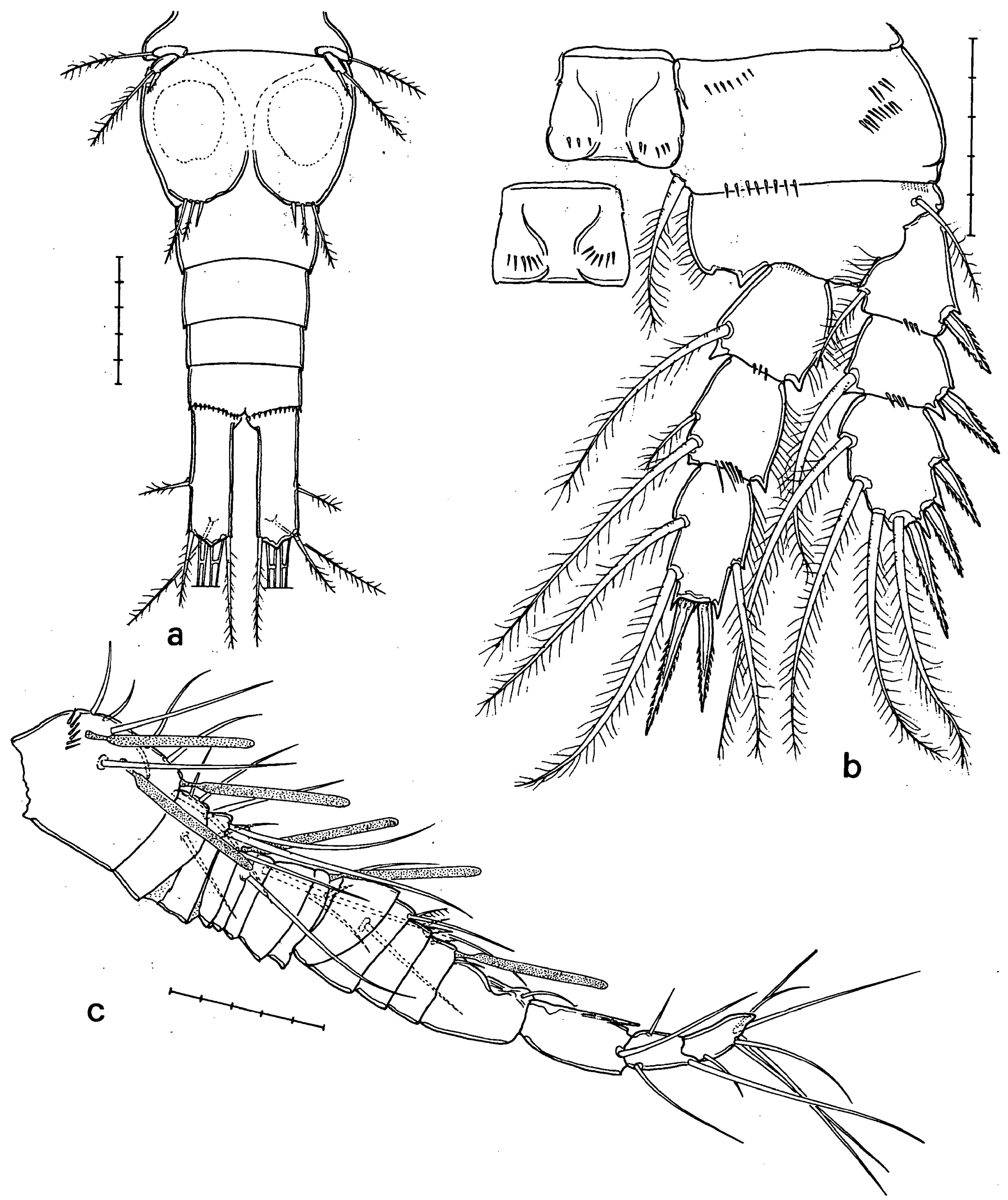

Fig. 4. Diacyclops cohabitatus male (a,c) and female (b) : a) abdomen and caudal rami, ventral view ; b) P4 ; c) antennule. Scale bars : $50 \mu \mathrm{m}$.

Fig. 4. Diacyclops cohabitatus mâle (a,c) et femelle (b) : a) abdomen et branches furcales, vue ventrale ; b) P4 ; c) antennule. Echelles : $50 \mu \mathrm{m}$. 
Distribution and habitat - Up to now, D. cohabitatus was known only from the type locality in the Carpathian Mountains, Ukraine (Monchenko, 1980). We detected $D$. cohabitatus in the groundwaters of the Lobau-wetland where it co-exists with $D$. felix and $D$. danielopoli. However, it is restricted to locations further away from surface waters, while $D$. felix even occurs in the bedsediments of the old arms of the Danube. In the Mausrodlhöhle, $D$. cohabitatus was sampled from a siphon pool (phreatic zone). Though $D$. cohabitatus is reported only from groundwaters, the morphological traits do not exhibit any degree of stygobitization.

\subsection{Diacyclops languidoides goticus (Kiefer 1931)}

Material examined : Well in Bad Vöslau, south of Vienna, 1 female (leg. J. Vornatscher, 22/03/1967), Kiefer collection (slide n. 7992, Staatliches Museum für Naturkunde, Karlsruhe).

Remarks : Diacyclops languidoides goticus, described by Kiefer (1931) from Slovenia, is probably a valid species (Stoch, unpublished), and a full redescription will be given elsewhere. Although the single specimen from Austria is damaged, its morphological characters (Fig. 5) matches well with those observed in the Slovenian populations: $D$. languidoides goticus can be easily differentiated from $D$. cohabitatus by the combination of the following characters : elongation of caudal rami (4.93 times longer than wide, Fig. 5a) ; ratio between terminal accessory seta and posterolateral seta (Fig. 5a) about 0.75 (versus 1.6 in D. cohabitatus) ; slightly shorter terminal spines of the third endopodal segment of P4 (ratio inner terminal spine versus segment 0.68 , Fig. $5 \mathrm{~d}$ ) ; ornamentation of intercoxal sclerites, with a double, continue row of spinules (Fig. 5d) ; longer spines of P6 (Fig. 5e). The spinulation pattern of the antennary basis (Fig. 5 b,c) in the two species is very similar.

Distribution and habitat : Up to now, D. l. goticus has been reported only from karstic groundwaters in Slovenia (Postojna-Planina cave system : Kiefer 1931 ; Brancelj 1987 as D. languidoides) drained into the Danube basin. The sampling station in Austria is located in the basin of the Triesting river, which flows into the Danube river close to the Lobau area.

\section{Discussion}

Currently, four species of the Diacyclops languidoides - group occur in Austria. Since there is extensive overlap of variability of some characters - such as the length of caudal rami, traditionally used in cyclopid taxonomy - between these closely related species, it is concluded that most early records reported as $D$. languidoides are unreliable, and probably $D$. languidoides (Lilljeborg, 1901) s.str. is not present in Austria.

The Austrian populations of $D$. cohabitatus are almost identical to the type material of $D$. cohabitatus illustrated by Monchenko (1980); the small differences regard the elongation of caudal rami and antennulary segments. The length of caudal rami is a very variable feature within species of Cyclopidae in general (Karaytug \& Boxshall 1998), and a high degree of variability within populations as well as between populations was reported by Stoch (in press) in the $D$. languidoides-group. Unfortunately, the variability of the length of antennulary segments in cyclopoid species remains unexplored. For these reasons the material from Austria is assigned here to $D$. cohabitatus.

A careful examination of the specimens collected in Mausrodlhöhle revealed that they belong to $D$. cohabitatus, although the very similar $D$. languidoides goticus was reported by Chappuis (1934) from the same cave, thus suggesting synonymy. However, the synonymy remains doubtful, because we cannot exclude definitely the presence of the latter taxon in the cave. D. languidoides goticus, until now only known from groundwaters in Slovenia, is probably a valid species according to careful examination of the existing material by one of us (Stoch, unpubl.). The only definitive record from Austria is a single specimen from Bad Vöslau which is damaged, but its morphological characters match well with those observed in the Slovenian populations.

Petkovski (1984) synonymized $D$. cohabitatus with D. zschokkei (Graeter, 1910) ; both species share the presence of the antennary exopodal seta. A detailed study of topotypic material of $D$. zschokkei from Switzerland, already redescribed by Lescher-Moutoué (1974), revealed that it can be differentiated from $D$. cohabitatus on the basis of the following characters : spinulation pattern of antennary basis ; terminal accessory seta longer than caudal ramus ; shorter distal spines of third endopodal segment of P4 ; presence of an additional row of spinules on intercoxal sclerite of P4.

Diacyclops cohabitatus is also closely related to three species described from central and southern Italy : D. lindae Pesce 1984, D. maggi Pesce \& Galassi 1987 and D. cristinae Pesce \& Galassi 1987. The taxonomic status of these taxa is under revision by one of us ( $F$. Stoch) ; they share the presence of an exopodal seta on antennary basis (see Pesce \& Galassi 1985, 1987 and Pospisil \& Stoch 1999 for a discussion on its taxonomic value), but differ from $D$. cohabitatus in the ab- 

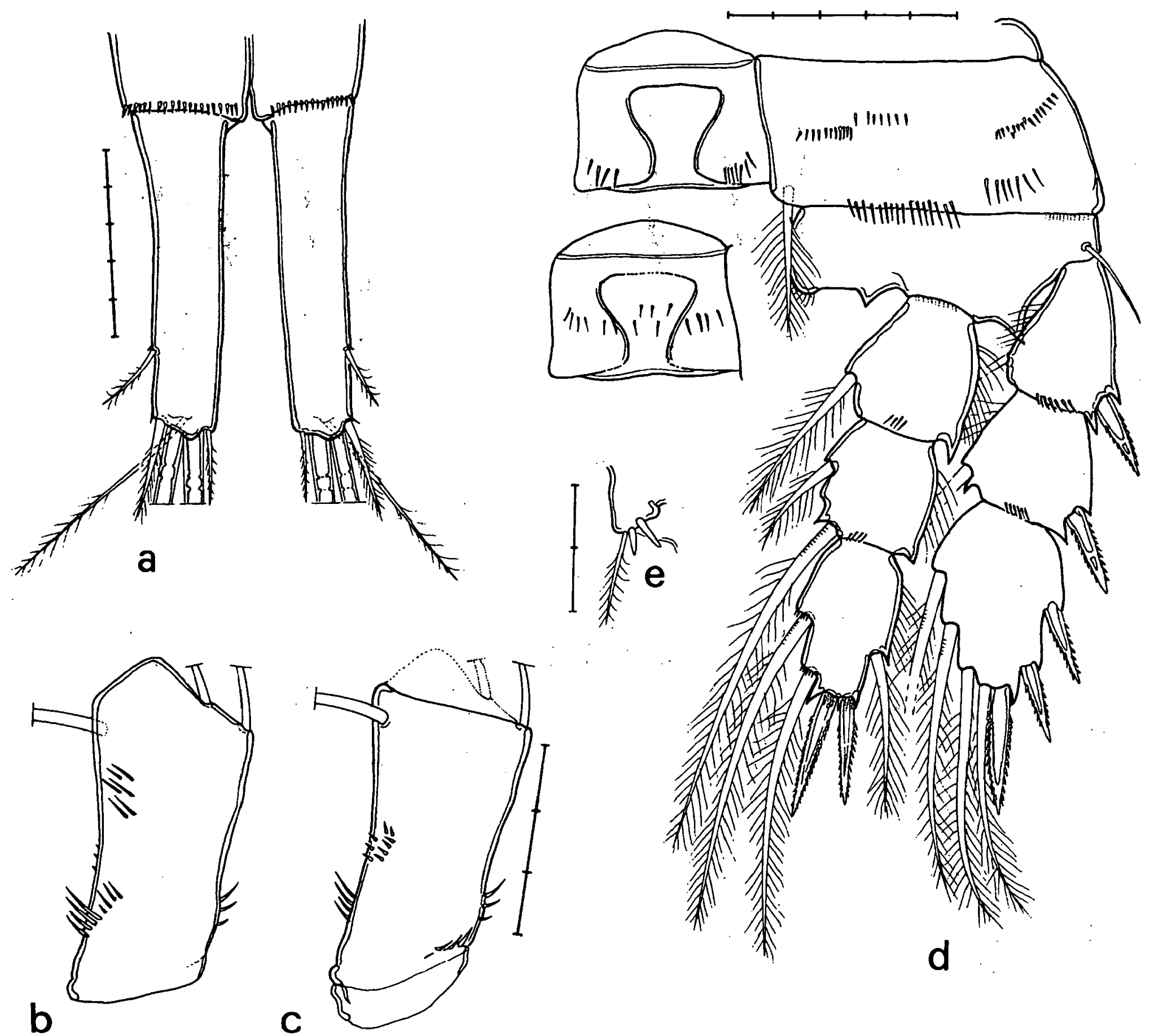

b
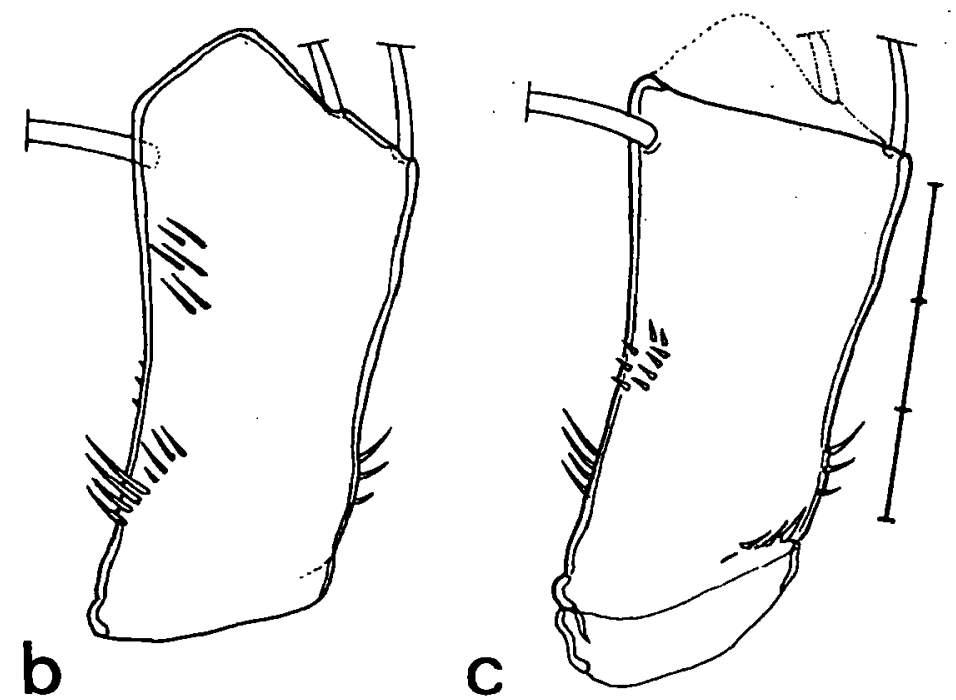

Fig. 5. Diacyclops languidoides goticus female : a) caudal rami, ventral view; b) antennary basis with spinule pattern, caudal side ; c) ibidem, frontal side ; d) P4 ; e) P6. Scale bars : $50 \mu \mathrm{m}$ (a, d), $30 \mu \mathrm{m}$ (b,c), $20 \mu \mathrm{m}$ (e).

Fig. 5. Diacyclops languidoides goticus femelle : a) branches furcales, vue ventrale ; b) basis de l'antenne avec la disposition des épines, face caudale ; c) de même, face frontale ; d) P4 ; e) P6. Echelles : $50 \mu \mathrm{m}(\mathrm{a}, \mathrm{d}), 30 \mu \mathrm{m}(\mathrm{b}, \mathrm{c}), 20 \mu \mathrm{m}(\mathrm{e})$.

sence of the notch on P4 basis and in some minor details of antennary structure and ornamentation. These previously overlooked characters have significant taxonomic value (Stoch, in press) and suggest the separation of the Italian material from $D$. cohabitatus at the species level ; however, its assignment to three different species can be questioned.

D. languidoides anatolicus (Pesce 1992) from Turkey, D. sardous Pesce \& Galassi 1987 and $D$. nuragicus Pesce \& Galassi 1985 from Sardinia are also closely related to the populations from peninsular Italy as well as to $D$. cohabitatus. Unfortunately, the descriptions lack sufficient detail, and the poor condition of the material at our disposal prevents us to compare these species with $D$. cohabitatus.

\section{Acknowledgements}

The authors are indebted to : Dan Danielopol (Institute of Limnology, Mondsee, Austria) for supporting this work in every possible way ; F. Lescher-Moutoué (École Normale Supérieure, Paris, France) for the helpful comments on an early draft of the manuscript and the loan of topotypic material of Diacyclops zschok$k e i$; H. Wittmann (Staatliches Museum für Naturkunde, Karlsruhe, 
Germany) for the loan of Diacyclops material from Kiefer collection ; G.L. Pesce and D.P. Galassi (University of L'Aquila, Italy) for the loan of comparison material from southern Italy ; the staff of the "Lobau" forest administration, R. Schreckeneder, G. Haubenberger, A. Placho, and H. Tomsic (Gross-Enzersdorf) for the help in the field and laboratory work. The Austrian Science Foundation «Fonds zur Förderung der wissenschaftlichen Forschung" (FWF-projects 7881-Bio and 11149-Bio) supported this work financially.

\section{References}

Brancelj A. 1987. - Cyclopoida and Calanoida (Crustacea, Copepoda) from the Postojna-Planina Cave System (Slovenia). Biol. Vestn., $35: 1-16$.

Chappuis P.A. 1934. - Ostalpine Höhlencopepoden. Bul. Soc. St. Cluj, 8 : 211-217.

Danielopol D. L. 1983. - Der Einfluß organischer Verschmutzung auf das Grundwasser-Ökosystem der Donau im Raum Wien und Niederösterreich. Forschungsberichte Bundesministerium für Gesundheit und Umweltschutz, $5: 1-155$.

Gaviria S. 1998. - Checklist and distribution of the free-living copepods (Arthropoda : Crustacea) from Austria. Ann. Naturhist. Mus. Wien, 100B : 539-594.

Huys R. \& Boxshall. 1991. - Copepod evolution. Ray Society, 159 : $468 \mathrm{p}$.

Karaytug S. \& Boxshall G.A. 1998. - The Paracyclops fimbriatuscomplex (Copepoda, Cyclopoida) : a revision. Zoosystema, 20 : 563-602.

Kiefer F. 1931. - Wenig bekannte und neue Süsswasser Copepoden aus Italien. Zool. Jahrb., Syst., 61 : 697-712:

Kiefer F. 1964. - Zur Kenntnis der subterranen Copepoden (Crustacea) Österreichs. Ann. Naturhist. Mus. Wien, 67 : 477-485.

Lescher-Moutoué F. 1974. - Cyclopides des eaux souterraines de l'Ain et de l'Isère (France). Ann. Spéléol., 29 : 335-349.

Löffler H. 1960a. - Die Entomostrakenfauna der Ziehbrunnen und einiger Quellen des nördlichen Burgenlandes. Wissenschaftliche Arbeiten aus dem Burgenland, 24 : 1-32.

Löffler H. 1960b. - 2. Beitrag zur Kenntnis der Entomostrakenfauna burgenländischer Brunnen und Quellen. Wissenschaftliche Arbeiten aus dem Burgenland, 26 : 1-15.

Monchenko V.I. 1980. - Rare and new for science Cyclops from the Diacyclops languidoides s.1. (Crustacea, Copepoda) group. Vestn. Zool., 6 : 12-19 (in Ukrainian).
Pesce G.L. \& Galassi D.P. 1985. - Due nuovi Diacyclops del complesso "languidoides" (Copepoda : Cyclopidae) di acque sotterranee di Sardegna e considerazioni sul significato evolutivo dell'antenna nei Copepodi stigobionti. Boll. Mus. civ. St. Nat., Verona, $12: 411-418$.

Pesce G.L. \& Galassi D.P. 1987. - New or rare species of Diacyclops Kiefer, 1927 (Copepoda, Cyclopoida) from different groundwater habitats in Italy. Hydrobiologia, 148: 103-114.

Petkovski T.K. 1984. - Bemerkenswerte Cyclopiden (Crustacea, Copepoda) aus den subterranen Gewässern Sloweniens. Acta Mus. Maced. Sci. Nat., $17: 23-52$.

Pospisil P. 1994 a. - Die Grundwassercyclopiden (Crustacea, Copepoda) der Lobau in Wien (Österreich) : faunistische, taxonomische und ökologische Untersuchungen. Ph. D. Thesis Univ. Vienna : 222 p.

Pospisil P. 1994 b. - The groundwater fauna of a Danube aquifer in the "Lobau" wetland in Vienna, Austria. In: Groundwater Ecology, Gibert J., D.L. Danielopol \& J.A. Standford ( eds.), Academic Press, San Diego : 347-366.

Pospisil P. \& Stoch F. 1997. - Rediscovery and redescription of Austriocyclops vindobonae Kiefer, 1964 (Copepoda, Cyclopoida) with remarks on the subfamily Eucyclopinae Kiefer. Crustaceana, 70 : 901-910.

Pospisil P. \& Stoch F. 1999. - Two new species of the Diacyclops languidoides - group (Copepoda, Cyclopoida) from groundwaters of Austria. Hydrobiologia, 412 : 165-176.

Priesel-Dichtl G. 1959. - Die Grundwasserfauna im Salzburger Becken und im anschliessenden Alpenvorland. Arch. Hydrobiol., $55: 281-370$.

Stoch F. (in press). - How many species of Diacyclops? New taxonomic characters and species richness in a freshwater cyclopid genus (Copepoda, Cyclopoida). Hydrobiologia.

Stoch F. \& Pospisil P. (in press). - Redescription of Diacyclops disjunctus (Thallwitz, 1927) from Austria with remarks on the Diacyclops languidus - group in Europe (Copepoda, Cyclopoida). Crustaceana.

Tilzer M. 1968. —Zu Ökologie und Besiedlung des hochalpinen hyporheischen Interstitials im Arlberggebiet (Österreich). Arch. Hydrobiol., 65 : 253-308.

Vornatscher J. 1972. - Die Tierwelt des Grundwassers - Leben im Dunkeln. In : Naturgeschichte Wiens. Arb. Inst. Wiss. Kunst, Hrsg., Band 2 : 659-674. 